\title{
Participation in Florida Growth Management Decisions ${ }^{1}$
}

Roy Carriker ${ }^{2}$

\section{Introduction}

The 1985 Growth Management Act gives residents of communities the right to become involved at all levels of the local comprehensive planning and land development process. What follows is an introduction to the subject of public participation in Florida's official growth management decision processes. This synopsis is offered as general information for members of the public who wish to participate in that process.

\section{Basic Requirements for Public Participation}

1. Each local government must give adequate public notice of each of its intended actions, usually by newspaper publication.

2. The local government must allow the public to participate in a meaningful way at noticed meetings and hearings before the local planning agency and the local governing body.

\section{Public Notification}

- Local governments are required to publish notices in the local newspaper whenever they intend to:
- Amend their local comprehensive plan.

- Amend land development regulations.

- Issue or deny some types of development orders.

- Notices for plan amendments and zoning actions that change the text or involve more than ten acres of land must be at least two columns wide and ten inches in length and must have a heading such as "Notice of Land Use Change," "Notice of Plan Amendments," "Notice of Zoning Change," or something similar.

- Notices may also include a map showing the location of the property that would be affected by the change.

- Notices must explain the time and place of hearings.

- Often, a notice will provide the name of a person to contact for more information.

- Once a notice is posted, the burden is on citizens to participate in the process, seek out necessary information, and follow through with written comments to the governing body.

1. This is EDIS document FE644, a publication of the Food and Resource Economics Department, Florida Cooperative Extension Service, Institute of Food and Agricultural Sciences, University of Florida, Gainesville, FL. Published August 2006. Please visit the EDIS website at http://edis.ifas.ufl.edu.

2. Roy Carriker, Professor, Food and Resource Economics Department, Florida Cooperative Extension Service, Institute of Food and Agricultural Sciences, University of Florida, Gainesville, FL.

The Institute of Food and Agricultural Sciences (IFAS) is an Equal Opportunity Institution authorized to provide research, educational information and other services only to individuals and institutions that function with non-discrimination with respect to race, creed, color, religion, age, disability, sex, sexual orientation, marital status, national origin, political opinions or affiliations. U.S. Department of Agriculture, Cooperative Extension Service, University of Florida, IFAS, Florida A. \& M. University Cooperative Extension Program, and Boards of County Commissioners Cooperating. Larry Arrington, Dean 
- By law, citizens have a right to all documents that are in the public record, although citizens requesting documents may be required to pay a reasonable cost of copying.

\section{Public Participation}

- Local governments may establish ground rules to govern the manner of public participation, such as rules of conduct at meetings, and time limits and locations for presentations.

- Citizens who comply with these rules must be allowed to have their say.

- Other laws, such as Florida's Sunshine Act and open records laws, also serve to ensure public access to documents and public officials.

\section{Advice Regarding Position Statements}

- Once you have formulated a position, clarify it in writing.

- Send a copy of your written position statement to each agency that will be considering the matter (e.g., local planning staffs and agencies, and local governing bodies).

- Be sure to include your name, address, and phone number on the material you submit.

- Request that your name be placed on a mailing list so that you will receive all future notices related to the amendments, land development regulations, or development orders.

- Follow up to make sure your written statement has been received by all parties.

- Keep a copy of all correspondence.

\section{Standing}

The submission of a written statement to the local government may help demonstrate that you have properly participated in the process in a manner that would give you standing later to challenge a decision that is adverse to your interests.

\section{Public Meetings}

- If a sign-in sheet is provided, record your presence.

- If you speak, speak from written materials. This helps keep your statements to the point.

- Provide a copy of your written materials to the presiding officer for the hearing.

- Keep a copy of your written materials for your own records.

- Remember, your written materials will become part of the record of the proceedings and can be used to prove your participation in the process for the purpose of establishing standing to challenge later actions.

\section{Resolving Differences Informally}

-While formal public participation is important, it may be possible to have your concerns addressed by communicating informally with developers, elected officials, appropriate staff, and other participants.

- Having your concerns and the concerns of other affected persons incorporated early in the plan amendment process may save time and be less costly for all parties involved.

\section{Additional Sources of Information on Public Participation}

A number of internet sites contain thorough and helpful information about all aspects of comprehensive planning and land development regulation in Florida. Two of the most comprehensive are maintained by 1000 Friends of Florida at http://www.1000friendsofflorida.org, and by the Florida Department of Community Affairs at http://www.dca.state.fl.us.

Other suggested reading includes EDIS documents FE642, Comprehensive Planning for Growth Management in Florida; FE643, Florida's Growth Management Act: An Introduction and Overview; and FE645, Florida Growth Management: Public Participation and the Plan Amendment Process. 